\title{
Contents Vol. 18,1986
}

\section{No. 1 Original Papers}

Distribution of Types I, II, III, IV and V Collagen in Normal and Keratoconus Corneas

Nakayasu, K.; Tanaka, M.; Konomi, H.; Hayashi, T 1

Bupranolol, A ßt- and B2-Blocker, Causes Constriction of the Pupil in Men

Tsukahara, S.; Sasaki, T.; Yamabayashi, S.; Shimizu, Y 11

Ultrastructural Analysis of Experimental Allergic Uveitis in Rabbit

Rao, N.A.; Brown, C.J.; Marak, G.E 15

Experimental Study of the Retinal Toxicity of Hemoglobinic Iron

Doly, M.; Bonhomme, B.; Vennat, J.C 21

Development of Ocular Mucin: Scanning EM Analysis

Hazlett, L.; Dudzik, D.; Harries, B 28

Effect of Pilocarpine on Intraocular Pressure in Ocular Hypertensive Subjects

Naveh-Floman, N.; Stahl, V.; Korczyn, A.D 34

Evaluation of the Burst Mode of a Neodymium: YAG Laser in Saline and Polymethyl

Methacrylate

Weckstrom, K.; Peyman, G.A

Modulation of Lens-Induced Uveitis by Superoxide Dismutase

Rao, N.A.; Calandra, A.J.; Sevanian, A.; Bowe, B.; Delmage, J.M.; Marak, G.E., Jr. . 41 Effects of Phenothiazines on Cultured Retinal Pigment Epithelial Cells

Matsumura, M.; Yamakawa, R.; Shirakawa, H.; Ogino, N

Postural Variations of Intraocular Pressure - Preflight Experiments for the DrMission

Draeger, J.; Hanke, K 55

No. 2 Original Papers

Lens Proteins in Intumescent Cataract

Ringens, P.J.; Bistervels, B.; Hoenders, H.J.; Wollensak, J 61

Topically Induced Ocular Anaphylaxis in Rats Immunized with Egg Albumin

Tromcé, S.T.; Tromcé, M.C.; Bloch, K.J.; Allansmith, M.R 68

Cytology of Human Intraocular Lenses. A Scanning Electron Microscopic Study

Kappelhof, J.P.; Vrensen, G.F.J.M.; Jong, P.T.V.M. de; Pameyer, J.H.; Willekens,

$$
\text { B.L.J.C } 75
$$

Experimental Studies with a High-Density Silicone Oil for Giant Retinal Tear

Mester, U.; Rothe, R.; Zubcov, A

Topographic Distribution of Water in Rhesus Monkey Vitreus

Castoro, J.A.; Bettelheim, F.A

87

Determination of the State and Content of Water in Normal Avian, Fish, Porcine, Bovine,

and Human Lenses as Studied by Differential Scanning Calorimetry

Lundgren, C.H.; Williams, T.R.; Nunnari, J.M 
Relation of Vitreous Amyloidosis to Prealbumin

Sandgren, O.; Westermark, P.; Stenkula, S

Metabolism of Glycoproteins in Cultured Retinal Pigment Epithelium

Entani, S.; Yoshimura, N.; Chihara, E.; Tsukahara, 1

104

Identification of Metabolic Risk Factors for Posterior Subcapsular Cataract

Jahn, C.E.; Janke, M.; Winowski, H.; Bergmann, K. v.; Leiss, O.; Hockwin, 0112

Determination of the State and Content of Water in Human Normal and Cataractous

Lenses by Differential Scanning Calorimetry

Nunnari, J.M.; Williams, T.R.; Powell, D.L 117

No. 3 Abstracts

26th Meeting of the Association for Eye Research, Leysin, Switzerland,

October 1-4, 1985

125

Original Papers

Ultrastructural Study of Rainbow Trout Lenses Incubated under Various Conditions

Uga, S.; Ishikawa, S.; Hikida, M.; Iwata, S 156

Decreased Fibronectin Levels in Aqueous Humor after Corneal Injury

Kenney, M.C.; Lewis, W.; Redding, J.; Waring, G.0165

Experimental Chloroquine Retinopathy

Matsumura, M.; Ohkuma, M.; Tsukahara, 1172

Ultrastructure of Posterior Subcapsular Cataract in Human Lens

Nagata, M.; Matsuura, H.; Fujinaga, Y 180

Antiphlogistic Effect of Catalase on Experimental Phacoanaphylactic Endophthalmitis

Rao, N.A.; Fernandez, M.A.S.; Sevanian, A.; Till, G.O.; Marak, G.E., Jr 185

Announcement 192

No. 4 Original Papers

Modulation of Lens-Induced Uveitis by Dimethyl Sulfoxide

Rao, N.A.; Bowe, B.E.; Sevanian, A.; Till, G.O.; Marak, G.E., Jr 193

Electron Microscopic Study of the Developing Human Vitreous Collagen Fibrils

Akiya, S.; Uemura, Y.; Tsuchiya, S.; Azuma, N.; Fujita, K 199

Hexamethyldisilazane in Preparation of Retinal Tissue for Scanning Electron Microscopy

Heegaard, S.; Jensen, O.A.; Prause, J.U 203

Vitamin D-Dependent Calcium Binding Protein Immunoreactivity in Human Retina

Verstappen, A.; Parmentier, M.; Chirnoaga, M.; Lawson, D.E.M.; Pasteels, J.L.;

Pochet, R 209

Influence of High-Dose Verapamil on Beagle Lens Proteins (Chronic Toxicity Test)

Bours, J.; Hockwin, O.; Schnitzlein, W.; Löhnert, G 215

Pattern and Flash Electroretinogram Following Increased Intraocular Pressure in Pigeons

Blondeau, P.; Olivier, P.; Brunette, J.R.; Zaharia, M.; Lafond, G 224

Replication of Scrapie Prions in Hamster Eyes Precedes Retinal Degeneration

Hogan, R.N.; Bowman, K.A.; Baringer, J.R.; Prusiner, S.B 230

Glutathione Synthesis in Evolution: An Achilles' Heel of Human and Other Old World

Simian Lenses

Rathbun, W.B 236

Contents 
In vivo Observations of Cataract Development in Emory Mouse (with 1 color plate)

Takizawa, A.; Sasaki, K 243

Effect of Topical Chemical Irritation on the Blood-Aqueous Barrier of the Rat Eye

Krootila, K.; Uusitalo, H.; Lehtosalo, J.I.; Palkama, A 248

No. 5 Original Papers

Deficient Autoregulation and Lengthening of the Diffusion Distance in the Anterior Optic

Nerve Circulation in Glaucoma: An Electro-Encephalo-Dynamographic Investigation

Ulrich, W.-D.; Ulrith, C; Bohne, B.-D 253

Relationship between Ciliary Perfusion Pressure and Pattern-Reversal Visual Evoked Cortical Potentials: An Electro-Encephalo-Dynamographic Investigation Ulrich, W.-D.; Ulrich, C; Bohne, B.-D.; Niederländer, C 260

Effects of Antiglaucoma Drugs on the Blood Flow in Rabbit Eyes

Chiou, G.C.Y.; Yan, H.-Y 265

Freezing-Thawing Hysteresis. I. NMR Detection in Human Lens

Pócsik, I.; Furó, I.; Rácz, P 270

Freezing-Thawing Hysteresis. II. Investigation of Human Ocular Tissues

Pócsik, I.; Furó, I.; Rácz, P 275

Effects of Dexamethasone Phosphate on the Formation of Ester Forms of Riboflavin in the

Lens

Ono, S.; Shimizu, S.; Takahashi, H.; Hirano, H 279

Species Survey of Glutathione Peroxidase and Glutathione Reductase: Search for an Animal Model of the Human Lens

Rathbun, W.B.; Bovis, M.G.; Holleschau, A.M 282

Further Evidence for the Involvement of Immunoregulatory Processes in Corneal Alkali

Burns: Effects of Immunosuppression and Convalescent Serum

Ben-Hanan, I.; Landshman, N.; Assia, E.; Belkin, M288

Orbital Tumor Diagnosis by Positron Emission Tomography Using 18F-Fluorodeoxyuridine

Kiyosawa, M.; Mizuno, K.; Ishiwata, K.; Watanuki, S.; Monma, M.; Ido, T.; Abe, Y.;

Fukuda, H.; Matsuzawa, T 292

Epidermal Growth Factor Increases Tensile Strength during Wound Healing

Petroutsos, G.; Sebag, J.; Courtois, Y299

Perimetric Profiles and Cortical Representation

Wood, J.M.; Wild, J.M.; Drasdo, N.; Crews, S.J 301

Possible Role of Galactose-1-P-Uridyl Transferase Activity Deficiency in Red Blood Cells

in the Development of the Presenile and Senile Cataract

Simonelli, F.; De Rosa, G.; Rinaldi, E.; Auricchio, L

Sorbitol Production in the Lens: A Means of Counteracting Glucose-Derived Osmotic

Stress

Chylack, L.T., Jr.; Tung, W.; Harding, R 313

No. 6 Original Papers

High-Voltage Electron Microscopy in Eye Research. Experimental Analysis of the Retinal

Pigment Epithelium and Choriocapillaris

Korte, G.E.; Heriot, W.; Pollack, A 321

A Simple Method for Controlled Freezing of Human Donor Corneae

Böhnke, M.; Draeger, J.; Rethwisch, K.; Stürmer, B 


\section{Contents}

Superoxide Dismutase Molecules in Human Cataractous Lenses

Scharf, J.; Dovrat, A 332

Growth Factors Induce Actin Disruption in Cultured Human Retinal Pigment Epithelial Cells

Shirakawa, H.; Yoshimura, N.; Ogino, N 338

High Performance Liquid Chromatography Determination of Cystathionase Activity in Human and Rabbit Lenses

Bergad, P.L.; Rathbun, W.B 343

Expression of the Antigens Recognized by Monoclonal Antibodies to Human Amnion (GB4, GB9, GB11) on the Rabbit Eye during Embryonic Development

Fredj-Reygrobellet, D.; Hsi, B.-L.; Yeh, C.-J.G.; Lapalus, Ph 349

Effects of Diabetes and Insulin Treatment on Sorbitol and Water of Rat Lenses

Coulter, J.B., III; Eaton, D.K.; Marr, L.K 357

Human Fetal Lens: Wet and Dry Weight with Increasing Gestational Age

Bours, J.; Födisch, H.J 363

Isotachophoresis of Human Fetal Lens Crystallins with Increasing Gestational Age

Bours, J.; Födisch, H.J 369

Author Index 373

Subject Index 376 